\title{
Hydrothermal vents and prebiotic chemistry: a review
}

\author{
María Colín-García, Alejandro Heredia, Guadalupe Cordero, Antoni Camprubí, \\ Alicia Negrón-Mendoza, Fernando Ortega-Gutiérrez, Hugo Beraldi, \\ Sergio Ramos-Bernal
}

\begin{abstract}
María Colín-García
mcolin@geologia.unam.mx

Fernando Ortega-Gutiérrez

Instituto de Geología, Universidad Nacional

Autónoma de México, Ciudad Universitaria, 04510,

Ciudad de México, México.

SIOV, Seminario Interdisciplinario sobre el Origen

de la Vida, Universidad Nacional Autónoma de

México, 04510, Ciudad de México, México.
\end{abstract}

\section{Alejandro Heredia}

Alicia Negrón-Mendoza

Sergio Ramos-Bernal

Instituto de Ciencias Nucleares, Universidad

Nacional Autónoma de México, 04510, Giudad de México, México.

SIOV, Seminario Interdisciplinario sobre el Origen de la Vida, Universidad Nacional Autónoma de

México, 04510, Ciudad de México, México.

\section{Guadalupe Cordero}

Instituto de Geofísica, Universidad Nacional

Autónoma de México, Ciudad Universitaria, 04510, Ciudad de México, México.

SIOV, Seminario Interdisciplinario sobre el Origen de la Vida, Universidad Nacional Autónoma de

México, 04510, Ciudad de México, México.

\section{Antoni Camprubi}

Instituto de Geología, Universidad Nacional

Autónoma de México, Ciudad Universitaria, 04510,

Ciudad de México, México.

\section{Hugo Beraldi}

SIOV, Seminario Interdisciplinario sobre el Origen de la Vida, Universidad Nacional Autónoma de México, 04510, Ciudad de México, México.

BOL. SOC. GEOL. MEX. 2016

VOL. 68 NO. 3

P. $599-620$

\section{ABSTRACT}

A hydrothermal system is an environment where there is a flow of hot fluids beneath and up to the surface of the Earth. Hydrothermal vents are systems whose heat source is the underlying magma or hot water generated by convection currents due to high thermal gradients. Hydrothermal fossil deposits have also been recognized in impact craters. Besides Earth, the other place in the Solar System that shows evidence of past impact-induced hydrothermal systems is Mars. The circulation of hydrothermal solutions and interaction with country rocks leads to the precipitation of different mineral phases. In fact, hydrothermal vents, due to their characteristics (redox potential, abundance of organic matter and the presence of certain minerals), have been proposed as places where chemical evolution could have occurred. In this article, a review of hydrothermal environments (submarine, subaerial and impact-induced) and their advantages and disadvantages as primitive environments is presented. Thus far, the synthesis of organic compounds in simulation experiments has been achieved, although the role of prebiotic processes in these environments is still ill-defined. The conditions accompanying white vents are perhaps the best suited for the synthesis of organic molecules; however, this synthesis could have also occurred around black vents, where favorable temperature gradients are present.

\section{Keywords: Submarine}

hydrothermal vents, subaerial hydrothermal springs, impact cratering, chemical evolution, origin of life.

\section{RESUMEN}

Un sistema hidrotermal involucra la circulación de fluidos calientes a profundidades variables en la corteza terrestre, y hasta la superficie. Las fuentes hidrotermales son sistemas cuyas fuentes de calor son magmas subyacentes o bien gradientes térmicos de diverso origen, que generan corrientes de convección en las que circula agua caliente. Los depósitos hidrotermales fósiles también han sido reconocidos en los cráteres de impacto. Además de la Tierra, el otro lugar en el Sistema Solar que presenta evidencias de actividad hidrotermal inducida por impacto es Marte. El proceso de circulación de las soluciones hidrotermales y su interacción con las rocas encajonantes es capaz de precipitar diferentes fases minerales. Las fuentes hidrotermales se han reconocido por sus características (potencial redox, fuentes abundantes de materia orgánica y presencia de minerales característicos) como lugares en los que la evolución quimica pudiera haberse producido. En este artículo se presenta una revisión de los ambientes hidrotermales (submarinos, subaéreos y de impacto), sus ventajas y desventajas como ambientes relevantes para la química prebiótica. Hasta el momento se ha logrado la sintesis de compuestos orgánicos en experimentos de simulación, aunque el papel de estos ambientes en procesos prebióticos aún es parte de un fuerte debate. Las condiciones presentes en los manantiales submarinos blancos son, quizá, las más adecuadas para que se presentara la síntesis de moléculas orgánicas; sin embargo, también pudo darse esta síntesis en los alrededores de los manantiales negros, donde se encuentran gradientes de temperatura favorables.

Palabras clave: Manantiales hidrotermales submarinos, manantiales hidrotermales subaéreos, craterismo de impacto, evolución química, origen de la vida. 


\section{Introduction}

Since its formation, the Earth has undergone many changes, among which one of the most remarkable has been the emergence of life. This must have occurred before $3500 \mathrm{Ma}$, the age of the rocks where the oldest known fossils have been found (Schopf, 2006). The event was preceded by a period called "chemical evolution", which involved chemical reactions among components of the ocean, the lithosphere and the early atmosphere. Life possibly emerged as a result of chemical processing in these media, with a continuous increase in molecular complexity (Morowitz, 2002). Multiple examples of water-based systems in which life could have arisen include seas and oceans, lakes, pools and ponds (plus other ephemeral water bodies), and intertidal zones.

The quest to explain how life originated on Earth is an old and unsolved topic. Several scientific hypotheses try to explain how life emerged as a result of the physicochemical interactions between organic molecules and the physical environment. The experimental evidence of chemical synthesis under conditions that possibly existed on early Earth provides support for the hypothesis of chemical evolution. The precise mechanism that led to the transformation of organic compounds to simple biological entities is still an open problem nonetheless. Two theories attempt to explain how life appeared: the "gene first" theory and the "metabolism first" approach (e.g., Bada and Lazcano, 2003; Delaye and Lazcano, 2005). According to the genetic approach, prebiotic soup produced organic compounds that gave rise to the first genetic systems; whereas the metabolic theory proposes the existence of a rudimentary primary metabolism (Orgel, 2000, Lazcano, 2010; Luisi, 2014). Both theories have been supported by several experimental as well as theoretical results (Orgel, 1998). Such is the case of the synthesis of many important organic compounds for present living beings - including some amino acids, nitrogenous bases, carboxylic acids and sugars. However, the formation of biological polymers, and how the relationship between proteins and nucleic acids evolved is still a far too complex and unresolved problem.

Either theory requires the synthesis of organic matter, which necessarily involves the participation of an energy source. Although there are many plausible energy sources for the generation of organic compounds, one of the most conspicuous sources on Earth is its internal heat, which is released in many environments. Such is the case of anomalously high thermal gradients around volcanoes and volcanic hot springs (Lathe, 2004, 2005), which can be subaerial and submarine -some with temperatures that may range from $90^{\circ}$ to $>$ $400{ }^{\circ} \mathrm{C}$ (Russell and Hall, 1997; Kelley et al., 2001). Processes driven by external sources for energy include many other interfaces such as those between rocks, water, air, and snow-air (Muller and Schulze-Makuch, 2006). From the point of view of prebiotic chemistry, high temperature gradients would have provided the necessary energy flux to promote chemical reactions. But at the same time, however, such gradients could have been harmful to organic compounds, thus promoting the degradation of the synthesized products (Muller and Schulze-Makuch, 2006).

For many years, a common feature in prebiotic experiments was their lack of any geological context. The discovery of hydrothermal vents in midocean ridges in the 1970s led many scientists to propose that these systems would make plausible geological sites for the origin of life (Holm and Charlou, 2001; Holm and Andersson, 2005). Most of these vents build up mineralized chimneys by means of hot fluids associated with Earth's mantle magmas at temperatures above $300^{\circ} \mathrm{C}$. French (1968, 1970) suggested that hydrothermal systems might have allowed organic compounds to be synthesized by non-biological processes through Fischer-Tropsch-like reactions (FT). These reactions involve gases at high pressures and temperatures, as well as minerals like siderite and other carbonates, sulfates, iron oxides, and some silicates. Those processes could have taken place at some depth within the Earth's crust, where organic matter 
could be produced, and then transferred to the surface (Holm and Andersson, 2005). Furthermore, Corliss et al. (1981) suggested that hydrothermal vents along mid-ocean ridges were likely sites for the origin and evolution of life. Also, Baross and Hoffman (1985) suggested that submarine hydrothermal systems have retained some characteristics, making them environments where reactions and evolutionary processes can be examined.

Such ideas began to gain importance when Wächtershäuser (1988 a, b) hypothesized that the first organisms on Earth could have been thermophilic and chemoautotrophic beings. These organisms could have had a primitive metabolism that took place on the surface of solid particles, especially sulfides (most likely, iron sulfides) that formed from hydrothermal venting (Wächtershäuser 1988 a, b). However, these ideas remain controversial and there is no compelling evidence to support that the first organisms were thermophilic. Regardless of how life originated, this process must be thermodynamically favored or it would have been unlikely (Martin and Russell, 2007). The chemical and thermal dynamics in hydrothermal vents makes such environments highly suitable thermodynamically for chemical evolution processes to take place. Therefore, thermal energy flux is a permanent agent and contributed to the evolution of the planet, including prebiotic chemistry.

\section{Hydrothermal systems and prebiotic synthesis}

A hydrothermal system is an environment where hot fluids circulate below the Earth's surface and may (or not) reach the surface as hot springs or vents. The two main components of a hydrothermal system are a heat source, and a fluid phase. In addition, fluid circulation requires faults, fractures and permeable lithologies (Pirajno, 2009).

Such systems can be classified according to their tectonic setting, the characteristics of their emplacement, and the sources for fluids, among other geological variables. As for the matter of prebio- tic synthesis, a variety of such environments have been invoked as likely sites to harbor the plausible chemical reactions thus involved. These are submarine and subaerial hydrothermal systems, and similar systems associated with impact cratering.

\subsection{SUBAQUEOUS HYDROTHERMAL SYSTEMS}

These hydrothermal systems (submarine or sublacustrine) can be divided into those linked to magmatism as both source for heat and chemical components, and those associated with venting of basinal brines. Such environments correspond, respectively, to volcanogenic massive sulfide (VMS) and sedimentary-exhalative (SEDEX) deposits and their present-day analogues. Paleo-hydrothermal systems associated with metalliferous deposits in black shales may be likely candidates as well. All theoretical and experimental approaches to prebiotic reactions have been carried out considering VMS-like hydrothermal systems, while neglecting the others. SEDEX systems and those associated with metalliferous black shales provide all geological and physicochemical characteristics that would have favored prebiotic reactions as effectively as VMS systems, like the necessary temperature gradients, euxinic environments, and a wide range of depths of formation (see Table 1). The problem in the involvement of SEDEX systems with prebiotic reactions resides in the age of the oldest examples of such systems, as no known deposits are older than late Paleoproterozoic (ca. 1.8 Ga; Lydon, 1996). Metalliferous black shales can be significantly older (middle Paleoproterozoic, ca. 2.1 Ga or older; Mossman et al., 2005) than SEDEX deposits. However, neither type has yet been found to be old enough as to be coeval with prebiotic processes or, least of all, be involved with them. In contrast, Archean VMS deposits are numerous (ca. 3.5 Ga; Barrie and Hannington, 1999). The striking lack of Archean SEDEX deposits can be associated with the limiting effect of high reduced iron contents on the activity of reduced sulfur in anoxic oceans (sic, Goodfellow, 1992) in which metals in hydrothermal fluids [...] were dispersed because a lack of reduced sulfur to precipitate them (sic, Misra, 1999). Therefore, 

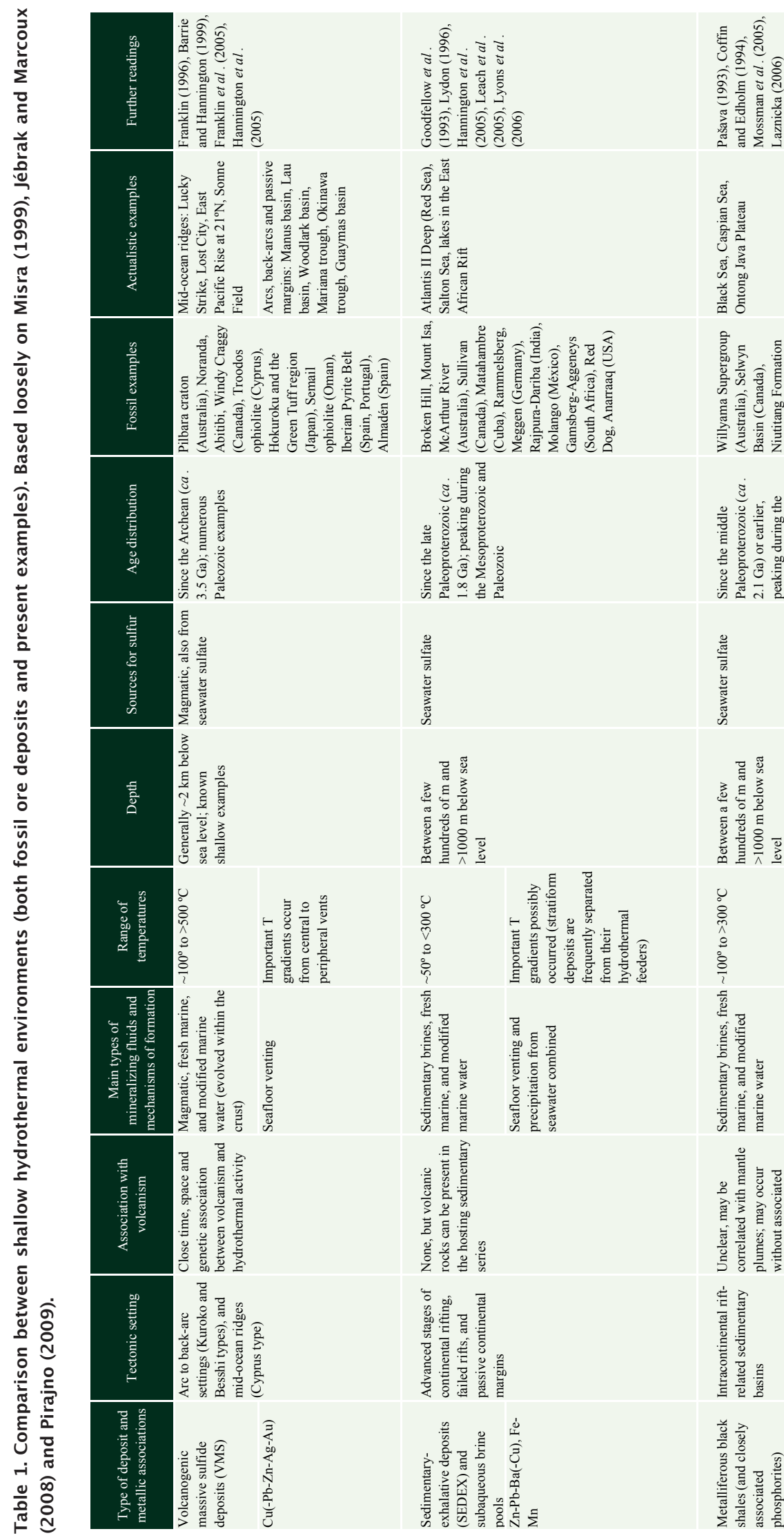

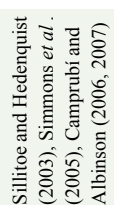
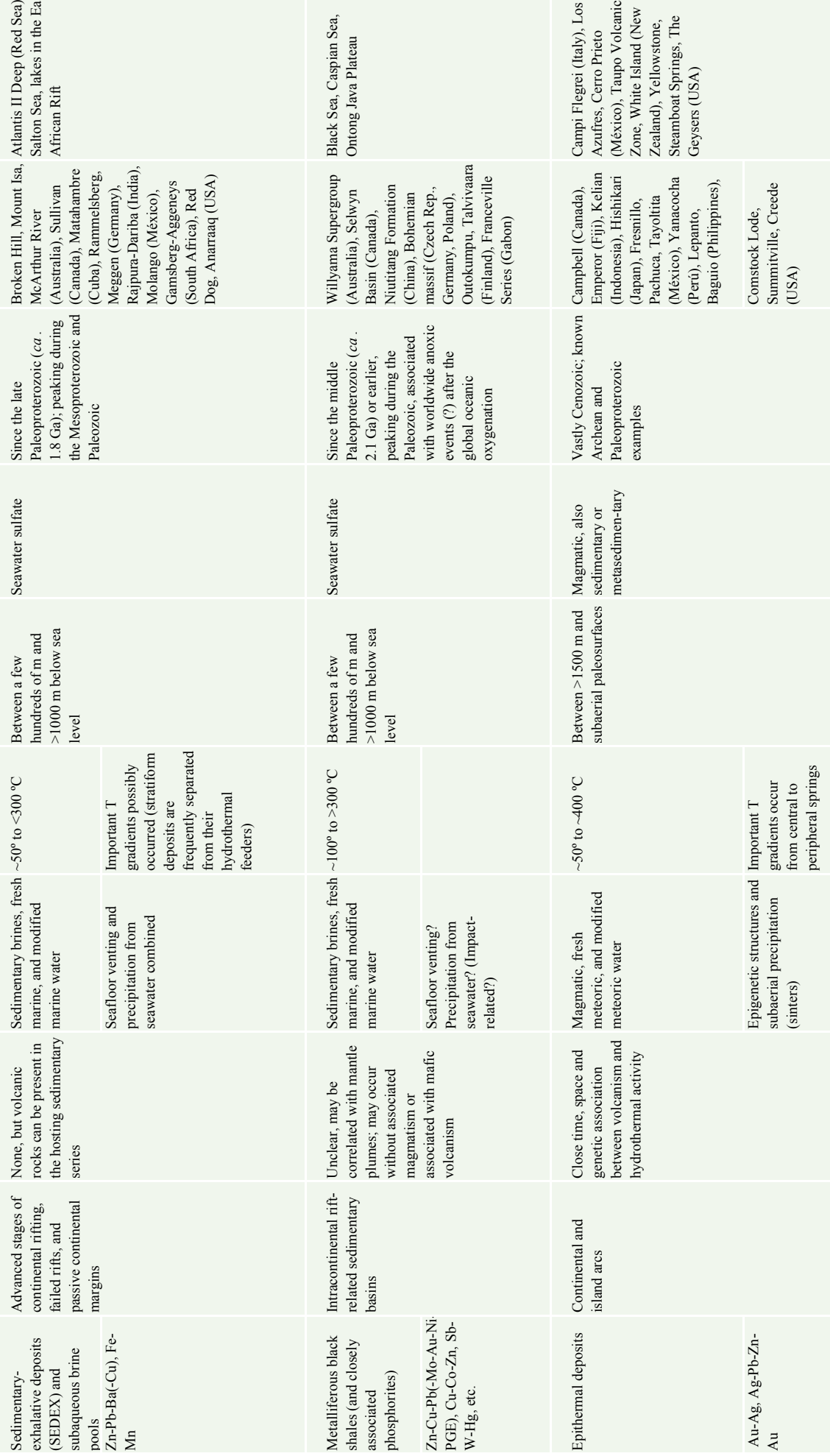
it is likely that SEDEX-type hydrothermal systems did effectively exist during the Archean, despite being unable to generate sulfide deposits because reduced sulfur in the oceans would have been previously "sequestered" by iron to precipitate iron sulfides directly from seawater. After the oxygenation of Earth's oceans SEDEX deposits formed, during worldwide anoxic events of the Paleozoic, as might also be the case for Proterozoic deposits (Misra, 1999).

Submarine vents in association with magmas at or near mid-ocean ridges are usually described as the likeliest hydrothermal systems to be associated with the emergence of life on Earth (i.e. Corliss et al., 1981, Nisbet and Sleep, 2001). Besides their possible role in the emergence and development of life on Earth, hydrothermal vents could sustain living organisms on Europa or Mars (Pope et al., 2006; Chyba and Phillips, 2007). The most common case for the formation of submarine hydrothermal vents occurs when seawater migrates through fractures into the crust and reaches the vicinity of a magmatic intrusion. While approaching the magmas, water is heated up by the anomalously high thermal gradient induced by their emplacement. Additionally, magmas release aqueous fluids upon their cooling down. Therefore, hydrothermal fluids in magma-related systems may come from either magmatic or marine sources. Similarly, sulfur, iron, copper, zinc and other metals may come from magmas, ocean water or host rock leachates. The dissolved minerals nourish chemosynthetic bacteria that constitute the base of the food chain for a variety of invertebrates, including large tubeworms (Levin, 2009).

The importance of submarine hydrothermal vents for studies related to the origin of life lies in: (1) providing hot water from shallow to surficial environments, (2) upwelling fluids interact with seawater, provide nutrients, are agents for chemical imbalance, thus potentially allowing the synthesis of organic compounds, (3) they produce a rapid crystallization of carbonates and silicates at low temperatures, which increases the local potential to preserve microbial organisms as fossils and their chemical signatures, despite later diagenetic or low-grade metamorphic processes (Pope et al., 2006), and (4) according to some authors, the oldest forms of terrestrial life might have been autotrophic-thermophiles (Pope et al., 2006).

The so-called "black smokers" are the most conspicuous submarine hydrothermal manifestations (Figure 1). These are hydrothermal fumaroles with abundant sulfides in suspension that upon precipitation form mounds along favorable faults or within submarine calderas. In association with divergent margins, these are usually located close to mid-ocean ridges. In these fumaroles, due to their proximity to magmas, water may attain temperatures above $400{ }^{\circ} \mathrm{C}$ and low $\mathrm{pH}$ (see Table 1). The latter facilitates the leaching of iron and other metals as the water seeps through the country rocks. Such fluids come in contact with cold seawater, thus generating a rapid nucleation of sulfides and other minerals and resulting in a turbid suspension resembling a cloud of black smoke.

Another type of hydrothermal vents is dubbed "white smokers", which are generally distant from their heat source (Figure 1); therefore, their temperatures are lower than those in black smokers. Black and white smokers may coexist in the same hydrothermal field, but they generally represent proximal and distal vents to the main upflow zone, respectively (Figure 1). However, white smokers correspond mostly to waning stages of such hydrothermal fields, as magmatic heat sources become progressively more distant from the source (due to magma crystallization) and hydrothermal fluids become dominated by seawater instead of magmatic water (see references in Table 1 for VMS systems). The temperature in white smokers can be as low as $40^{\circ}$ to $75^{\circ} \mathrm{C}$ and are alkaline (pH between 9 and 9.8; Kelley et al., 2001). Mineralizing fluids from this type of vents are rich in calcium and they form dominantly sulfate-rich (i.e., barite and anhydrite) and carbonate deposits. These may form giant chimneys, the largest of which stand almost $60 \mathrm{~m}$ above the bottom of the ocean (Figure 2) at the Lost City hydrothermal field (Kelley et al., 2001). Hydrothermal fluids in this location con- 


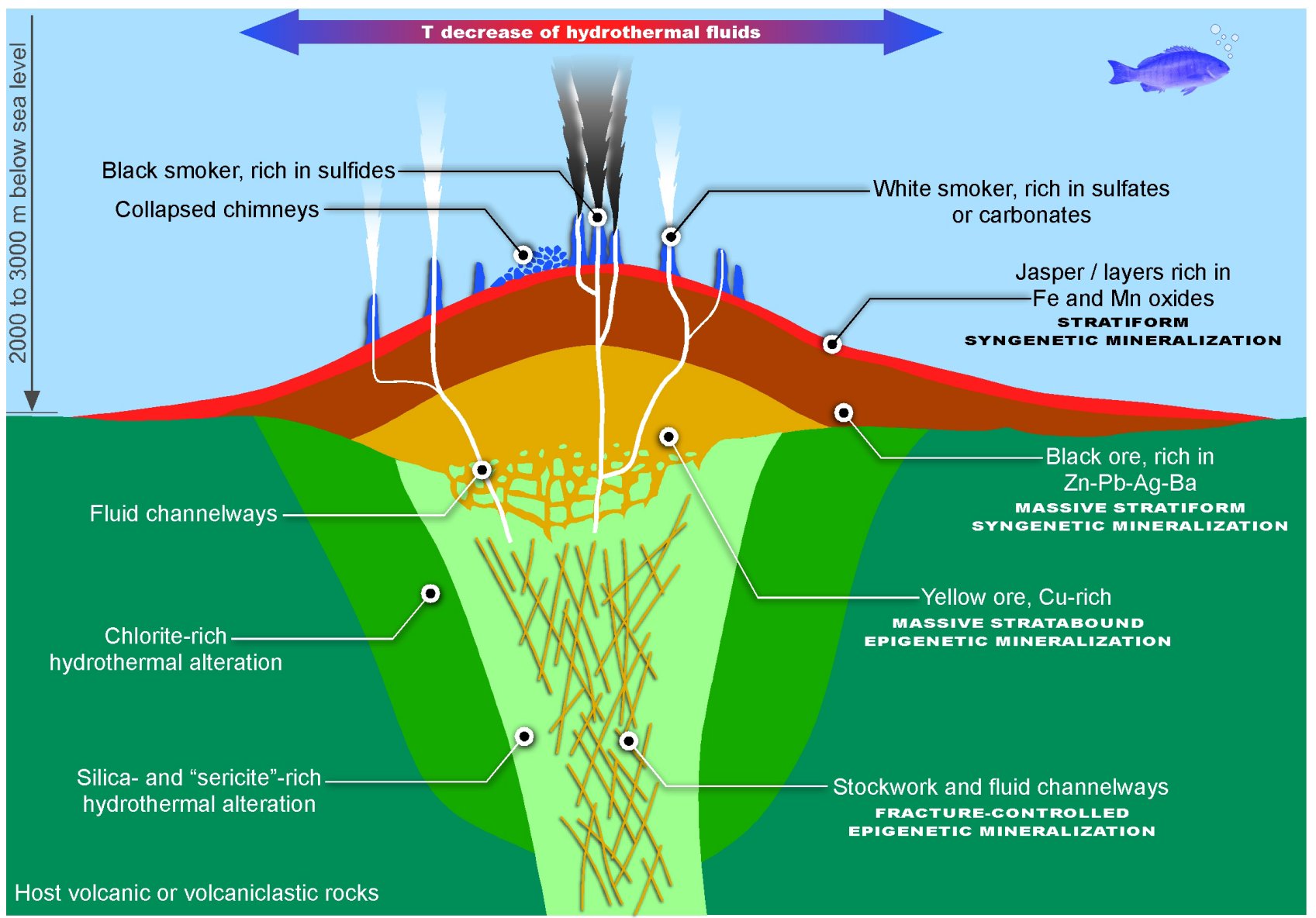

Figure 1 Structural section that combines evidence from active submarine magmatic-hydrothermal vents and from fossil volcanogenic massive sulfide (VMS) deposits, especially in Kuroko-type settings, including all typical styles of mineralization and hydrothermal assemblages. Based on Lydon (1988) and Hannington et al. (1995). Key: T = temperature.

tain methane, ethane and propane, and organic acids such as formate and acetate form in association with this hydrothermal system (Proskurowski et al., 2008).

The global frequency distribution of depths for the occurrence of actualistic examples of VMS deposits (magmatic-hydrothermal seafloor vents, either black or white smokers) shows a dominant range between 2000 and $3000 \mathrm{~m}$ (Figure 3; also, Figures 2 and 3 in Hannington et al., 2005), which is consistent with calculated depths of fossil examples (see Table 1 and references therein). In spite of this, much shallower examples are known both in present-day manifestations (Figure 3) as well as in fossil VMS deposits (e.g., Camprubí et al., 2017). Their global frequency distributions in latitude and longitude, however, are not expected to be clear because such spatial variables do not govern any geological characteristics for the location of venting. In fact, the present-day convergent or divergent margins that are capable of sustaining hydrothermal manifestations analogous to VMS deposits (see Figure 1 in Hannington et al., 2005) can be found in a wide variety of latitudes and longitudes, including divergent margins within the Arctic Circle and the convergent margin adjacent to the Antarctic Peninsula. However, the latitudinal distribution of those vents shows a bimodal pattern between $40^{\circ} \mathrm{N}$ and $40^{\circ} \mathrm{S}$ (Figure 2), which includes different types of both convergent and divergent margins (see Figure 1 in Hannington et al., 2005). The distribution is deemed to be an artifact due to the difficulties of carrying out oceanographic campaigns in extremely low latitudes, either 


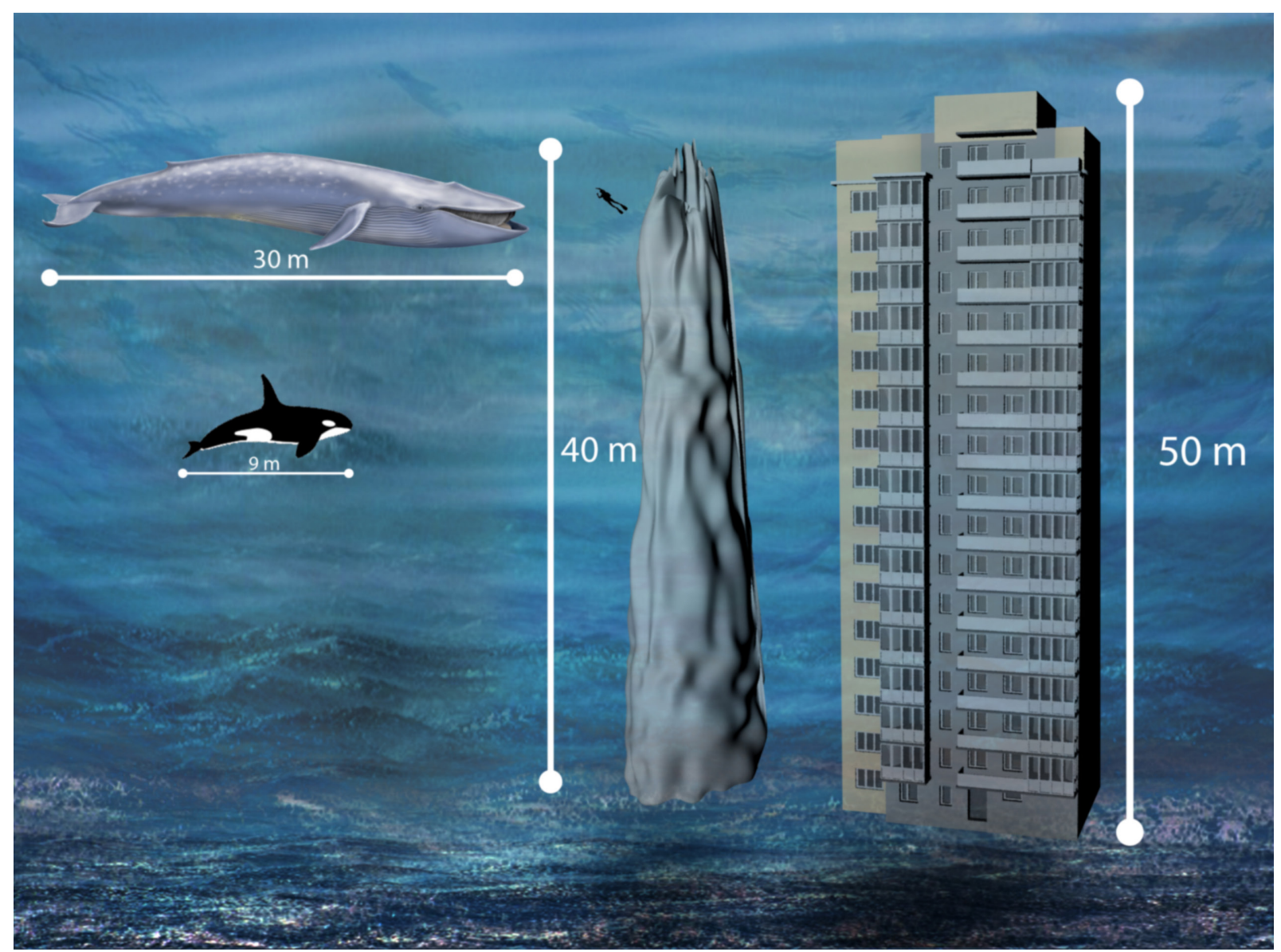

Figure 2 Size of hydrothermal chimneys in the Lost City Hydrothermal Field, compared to those of a blue whale, an orca, a 17-story building, and a diver.

north or south, in comparison with peri-equatorial regions.

\subsection{SUBAERIAL HYDROTHERMAL SYSTEMS}

Hydrothermal manifestations are abundant in subaerial settings, particularly in association with convergent plate boundaries (that is, continental and island volcanic arcs), but also in transform boundaries. For instance, hydrothermal activity is known to occur in the Salton Sea, in association with the San Andreas fault system but, unlike volcanic arcs, this case is normally placed among modern equivalents to SEDEX deposits and subaqueous brine pools (see Table 1). The most relevant and numerous recent/active hydrothermal fields are found in geothermal and magmatic-hydrothermal contexts, which are normally consi- dered as the modern analogues of low-sulfidation and high-sulfidation epithermal deposits, respectively (which, in both cases, may include intermediate-sulfidation deposits; Simmons et al., 2005; Camprubí and Albinson, 2006, 2007; Sillitoe, 2015). The uppermost part of such systems has a tendency to display wide variations in temperature, salinity, volatile content, $\mathrm{pH}$ and redox potential, hence the broad range in reactivity between the associated hydrothermal fluids and host rocks. Such variables are largely controlled by the vertical or lateral nearness of hydrothermal discharge zones to their parental intrusions (see Figure 1 in Sillitoe, 2015) and the geological and hydrological characteristics in each area (White and Hedenquist, 1990). Besides the broad temperature and salinity gradients that may occur in the actual va- 

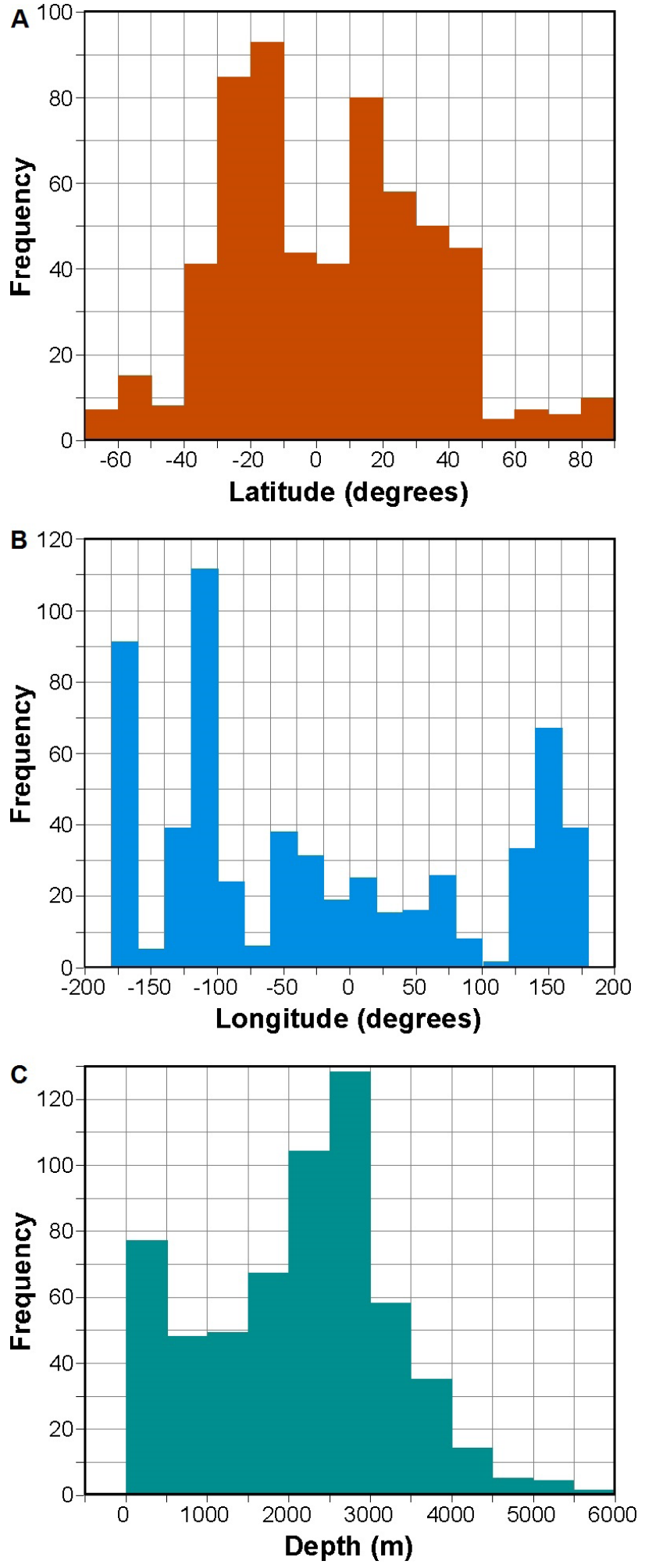

Figure 3 Frequency histograms for the geographical distribution of submarine hydrothermal vents worldwide, regarding (A) latitude, (B) longitude, and (C) depth, constructed by using the InterRidge Vents Database 3.3 (http://vents-data.interridge.org) dated April 30 2014. riety of such environments, the occurrence of deep hypogene low- to intermediate-sulfidation fluids (generally near-neutral and reduced; geothermal context) or high- to intermediate-sulfidation fluids (acidic and oxidized; magmatic-hydrothermal context) determines (1) the possible zonation of alteration assemblages around the fluid conduits, and (2) the mineralogy of the mineral precipitates (if any) that may occur on the surface. In addition to the "original" physicochemical characteristics of hydrothermal fluids, their chemical characteristics may vary depending on the occurrence of (relatively) near-surface boiling, which may generate $\mathrm{H}_{2} \mathrm{SO}_{4}$-rich fluids locally in steam-heated grounds (shallow hypogene acidic fluids), independently from the composition of pre-boiling fluids (e.g, Sillitoe, 2015). This means that hydrothermal fluids of any kind that undergo boiling may generate acidic fluids upon condensation of boiled-off steam, and the associated alteration assemblages and surficial hydrothermal features.

Acidic fluids from either deep or shallow hypogene sources generate alteration assemblages that result from extremely reactive to relatively mild reactions between fluids and host rocks, from proximal to distal areas to hydrothermal upflow, respectively. No surface sinter deposits, either carbonate- or silica-rich, can be expected from highly reactive high-sulfidation type fluids. In this environment, silica is the only residue after extreme acid leaching of every other mineral, or as a late overprint. Common hydrothermal manifestations of the high-sulfidation type are high-temperature solfataras and fumaroles centered on recent volcanic edifices, and hyper-acidic crater lakes. Near-neutral low-sulfidation type fluids, on the contrary, may develop sinter deposits in hot spring environments unless the hydrothermal discharge occurs in high-relief terrains. Common hydrothermal manifestations of the low-sulfidation type are hot springs and geysers. Common manifestations associated with steam-heated grounds are fumaroles, steaming grounds, and mud pots (or mud "volcanoes"). The position of the groundwater table is sensitive to seasonal variations in rainwater 
availability, climatic and tectonic changes, or several other phenomena (e.g, Sillitoe, 2015).

\subsection{IMPACT CRATERING AND HYDROTHERMAL SYSTEMS}

Impact cratering is a major geological process that occurs on the Earth and all other solid bodies of the Solar System. Impact cratering alludes to a process in which an asteroid or comet at high speed collides with a planetary surface, producing a cavity known as an impact crater (Melosh et al., 1990; Melosh, 2011). Temperatures and pressures produced by the collision are typically $>10000 \mathrm{~K}$ and a few hundred GPa, respectively. For comparison, in the Earth's core, the pressure is estimated at $\sim 350 \mathrm{GPa}$ and temperature at $\sim 5000 \mathrm{~K}$. Under these conditions, both the target and projectile material melt or vaporize near the point of contact (Collins et al., 2012).

Since Alvarez et al. (1980) proposed a possible extraterrestrial impact to explain the mass extinction at the K-T (Cretaceous-Cenozoic) boundary; extensive work has been carried out to try to understand the consequences of an impact due to objects larger than one $\mathrm{km}$ in diameter. An object $10 \mathrm{~km}$ across, similar to the one that formed the Chicxulub crater in the Yucatán Peninsula, would throw a huge amount of dust into the air, thus blocking sunlight and inhibiting photosynthesis and cutting off heterotrophs' primary food source. Also, the ejecta that failed to escape Earth's gravitational pull would reenter the atmosphere and raise the atmospheric temperature enough to cause global forest fires (Melosh et al., 1990; Kring and Durda, 2002). Although, at first glance, such impacts may prevent life from developing instead of being favorable for it, some positive effects can be expected. For example, in recent years scientists have retaken the idea that prebiotic compounds, water, and other gaseous components that are now present on Earth were brought and deposited by asteroids and comets that collided with the planet (Bernstein et al., 1999; Horneck, 2006).

The first authors who propose that impact craters may produce hydrothermal systems were AlDahan
(1990), Kring (1995), and McCarville and Crossey (1996). This was sustained because pressures and temperatures during the contact and compression stage are capable of melting the country rocks (Melosh et al., 1990). Such melts act as heat sources for hydrothermal systems in impact craters as the associated high geothermal gradient is established (Newsom, 2012). This proposal has been supported by hydrothermal deposits that have been recognized in the Chicxulub, Sudbury and Haughton impact craters (Kring, 1995; Osinski et al., 2005; Ames et al., 2006; Parnell et al., 2006). In fact, there is evidence of impact-induced hydrothermal systems in 60 out of the 181 confirmed terrestrial impact craters (Kirsimäe and Osinski, 2012).

The life span calculated for these systems is in the order of $10^{4}-10^{5}$ years if the crater is $100 \mathrm{~km}$ in diameter, and up to $10^{6}$ years for a $180 \mathrm{~km}$ crater like Chicxulub (Daubar and Kring, 2001). Magma-related hydrothermal activity may normally last in the order of $10^{5}-10^{6}$ years, even several million years, for epithermal and porphyry-related deposits, including similar subaerial active geothermal systems (Cathles et al., 1997; Arehart et al., 2002; Camprubí and Albinson, 2007; Baumgartner et al., 2009; Redmond and Einaudi, 2010; Chiaradia et al., 2013). Single fossil VMS deposits also exhibit similar age spans (e.g., Ross et al., 2014; Belford et al., 2015), and thus the temporal likelihood for all these types of hydrothermal systems to have roles in prebiotic chemistry is essentially the same.

Besides Earth, the other place in the inner Solar System that presents evidence of impact-induced hydrothermal systems is Mars (Rathbun and Squyres, 2002; Pirajno, 2009). As less energy is necessary to produce an impact crater of any size on Mars than on Earth, so would be the volume of molten rock that could be produced in Mars. Therefore, it is expected that for similar craters on Mars and Earth, the hydrothermal activity on Mars would be shorter in duration than on Earth by about an order of magnitude (Pope et al., 2006). Another interesting aspect about craters on Mars 
is that they could have been occupied by paleolakes. These could have existed over thousands of years as crater lakes, much like as on Earth, covered by an ice layer and heated from below by impact melts (Kirsimäe and Osinski, 2012). Phyllosilicates have been detected in impact-induced hydrothermal systems on Mars (Kirsimäe and Osinski, 2012); these minerals have been proposed as natural catalysts for prebiotic reactions.

It has been considered that the main sources for fluids in an impact-induced hydrothermal system would be seawater and meteoric water. The chemical composition of these fluids depends on the composition of the ground that received the impact (or target material). In this kind of systems, $\mathrm{Ca}-\mathrm{Mg}$ or K-rich minerals will dominate depending on the target material, the size of the impact crater, the sources for fluids and the evolution of the hydrothermal system. Usually, Na-K minerals dominate at the beginning of the lifetime of the hydrothermal system, and evolve into Ca-Mg minerals at the last phase of the impact cooling. For example, in the early stages of such hydrothermal activity, magmatic feldspars (plagioclase, microcline) are replaced by hydrothermal alkali feldspars (albite, "pericline"- and "adularia"-type potassium feldspar). During waning stages of hydrothermal systems, calcite and dolomite can precipitate depending on the enrichment of $\mathrm{Ca}$ and $\mathrm{Mg}$ in the fluids (Kirsimäe and Osinski, 2012).

\section{Minerals in hydrothermal vent systems}

Mineral parageneses are a key for the definition of physicochemical parameters that characterize the conditions for mineral precipitation, including timing. Mineralization in submarine magmatic-hydrothermal systems is a product of the chemical and thermal exchange between the ocean, the lithosphere, and the magmas emplaced within it. Different mineral associations precipitate during the typical stages of mineralization that characterize the life span of such systems. For comprehen- sive reviews of this subject see Franklin et al. (1981, 2005), Lydon (1988), Ohmoto (1996), Barrie and Hannington (1999), Hannington et al. (2005). Minerals present in a hydrothermal system or a fossil VMS deposit are deposited passively or reactively. Mineral associations may vary (1) in different mineralized structures, either syngenetic (namely, passive precipitation in chimneys, mounds and stratiform deposits) or epigenetic (structures that correspond to feeder channels, and replacements of host rocks or pre-existing massive sulfide bodies), or structural zonation, (2) from proximal to distal associations with respect to venting areas within the same stratigraphic horizon, or horizontal zonation, (3) from deep to shallow associations (i.e., stockworks to mounds), or vertical zonation, (4) from early and climactic to late stages of mineralization (dominated by sulfides, and sulfates or oxides, respectively), or temporal zonation, and (5) in various volcano sedimentary contexts, depending essentially on the composition of volcanic rocks and, ultimately, on the tectonomagmatic context. The most common minerals in ore-bearing associations of VMS deposits (non-metamorphosed or oxidized) and their modern analogues are pyrite, pyrrhotite, chalcopyrite, covellite, sphalerite, galena, tetrahedrite-tennantite, marcasite, realgar, orpiment, proustite-pyrargyrite, wurtzite, stannite (sulfides), Mn oxides, cassiterite, magnetite, hematite (oxides), barite, anhydrite (sulfates), calcite, siderite (carbonates) quartz and native gold, and are differently distributed in the various associations schematized above. The most common hydrothermal alteration assemblages are chloritic (including Mg-rich ones) and phyllic (dominated by "sericite", mostly illite), and also silicification, deep and shallow talcose alteration, and ferruginous (including Fe oxides, carbonates and sulfides) alteration. Paleosurface features for the various types of subaerial/sublacustrine magmatic - hydrothermal systems (that is, epithermal-like systems) and their mineralogy were summarized in detail by Sillitoe (2015) as (1) steam-heated grounds, with opal/ chalcedony, alunite, kaolinite and smectite, (2) groundwater table silicification, with opal/chal- 
cedony, (3) lacustrine amorphous silica sediments, with opal and cristobalite, (4) hydrothermal eruption craters and breccias, with illite and smectite, (5) hot spring sinter, with opal/chalcedony, (6) hot spring travertine, with calcite and aragonite, (7) hydrothermal chert, with opal/chalcedony, and (8) silicified lacustrine sediments, with opal/ chalcedony. See their occurrence and nature schematized in Figure 11 by Sillitoe (2015), as replacements, open-space or on-surface (subaerial or subaqueous) precipitation. Cases 6 to 8 (particularly case 6) occur distally to their hydrothermal upflow zone, which implies that their temperatures are lower than in proximal features, and their chemical characteristics attenuated by interaction with meteoric water. Such features and their particular mineral assemblages may be found topping various hydrothermal alteration assemblages in association with either acidic or near-neutral to alkaline fluids (high-sulfidation, and intermediateto low-sulfidation fluids, respectively), but not necessarily. Alteration assemblages in the uppermost part of these systems are characteristically zoned as follows, from the central portion of hydrothermal upflow outwards into non-altered host rocks (see Stoffregen, 1987; Corbett and Leach, 1998; Camprubí and Albinson, 2006, 2007):

1. high-sulfidation systems: residual quartz (with opal, cristobalite and tridymite), advanced argillic (from silica + alunite, to alunite + kaolinite outwards), argillic (from kaolinite + silica, to kaolinite + silica + smectite outwards), illite- or smectite-rich phyllic, montmorillonite-to chlorite-rich propylitic alteration, including zeolites and carbonates (calcite and dolomite) in association with the most alkaline fluids;

2. intermediate- to low-sulfidation systems: phyllic to propylitic alteration, with the same mineral assemblages as those described for high-sulfidation systems.

Additionally, all the features in the uppermost portions of epithermal deposits and their modern analogues may have anomalously high concentrations of Mn, As, Sb, Hg, Tl, Se, Au, Ag, Ga and W (Hedenquist et al., 2000; Sillitoe, 2015). These anomalies occur in association with minerals like pyrite, cinnabar, stibnite, orpiment, realgar, native sulfur, livingstonite, corderoite, several amorphous phases and, exceptionally, borates (Sillitoe, 2015, and references therein).

\section{Hydrothermal vents and chemical evolution}

In the field of chemical evolution, the search for a suitable location for chemical reactions to occur constitutes a major issue. Hydrothermal vents are environments that harbor very special physical, chemical and geological conditions, which could have been important for chemical evolution. On the one hand, the exergonic reactions in such systems could have been a source of free energy that promoted chemical reactions. This energy could eventually lead to the synthesis of prebiotic organic molecules, primarily from carbon dioxide reduction into hydrocarbons (Berndt et al., 1996), but also via methane oxidation and phosphate condensation (Russell et al., 2013).

On the other hand, probably one of the most important characteristics of hydrothermal vents is their high mineralogical diversity. A broad array of minerals could have acted as catalytic inorganic surfaces that favored the formation of organic molecules. Such mineralogical complexity implies the induction of important chemical gradients, thus favoring the interaction between electron donors (e.g., methane, hydrogen, formate) and electron acceptors (e.g., carbon dioxide, nitrate, nitrite, sulfite, native sulfur and ferric iron). As a consequence, these reactions would yield complex organic molecules aided by $\mathrm{pH}$ and thermal gradients, and perhaps also by mineral fracturing and fluid flow (Russell and Hall, 1997; Russell et al., 2013).

There are numerous experiments proposed to test the role of hydrothermal vents in prebiotic synthesis. A review of the literature (Tables 2, 3 and 4) indicates several types of experiments that can be performed. The first group is related to decomposition experiments, sometimes referred as 
Table 2. Experiments of decomposition and stability of organic molecules in physicochemical conditions that simulate those of hydrothermal vents.

\begin{tabular}{|c|c|c|c|c|c|}
\hline Type of Study & Description of experiments & Organic molecule used & Mineral & Main findings & Reference \\
\hline Decomposition & $\begin{array}{l}\text { Solutions of amino acids sealed in Pyrex } \\
\text { glass. }\end{array}$ & $\begin{array}{l}\text { Ala, Arg.HCl, Asp, Cys, Glu, } \\
\text { Gly, His.HCl, Hyp Pro, Ile, Leu, } \\
\text { Lys.HCl, Met, Phe, Pro, Ser, Thr, } \\
\text { Tyr,Val }\end{array}$ & N.A. & $\begin{array}{l}\text { Interconversion of amino acids (i.e. methylamine from } \\
\text { glycine; ethylamine from alanine; glycine, alanine and } \\
\text { ethanolamine from serine, etc.). } \\
\text { There is an order of relative thermal stability at } \\
\text { temperatures between } 216 \text { and } 280^{\circ} \mathrm{C} \text { ( (1) Asp, Thr, Ser, } \\
\text { Arg.HCl; (2) Lys-HCl, His-HCl, Met; (3) Tyr, Gly, Val, } \\
\text { Leu, Ile; (4) Ala, Pro, Hyp, Glu. }\end{array}$ & Vallentyne (1964). \\
\hline Decomposition & Amino acid in water solutions. & Glu, PCA. & N.A. & Kinetic parameters & Povoledo and Vallentyne, (1964). \\
\hline Decomposition & $\begin{array}{l}\text { Amino acid decomposition ( } 6 \mathrm{~h} \text { of } \\
\text { incubation at } 250^{\circ} \mathrm{C} \text { and } 260 \mathrm{bar} \text { ). }\end{array}$ & $\begin{array}{l}\text { Ala, Arg, Asp, Glu, Gly, His, Ile, } \\
\text { Leu, Lys, Met, Phe, Ser, Thr, Tyr, } \\
\text { Val. }\end{array}$ & N.A. & $\begin{array}{l}\text { Amino acids are drastically affected by high temperature } \\
\text { and pressure. Some amino acids are almost quantitatively } \\
\text { transformed or decomposed (Asp, Glu, Ser, Thr, Cys, } \\
\text { Trp); apolar amino acids as well as His, Lys, Arg and Phe } \\
\text { are partially degraded. }\end{array}$ & Bernhardt et al. (1984). \\
\hline Decomposition & $\begin{array}{l}\text { Amino acid and oligomer at high } \\
\text { temperatures, at both high and low pressure. }\end{array}$ & Gly, Di-Gly, L-Ala, L-Glu. & Magnetite & $\begin{array}{l}\text { Dipeptide hydrolysis and amino acid decomposition have a } \\
\text { first order rate-law. } \\
\text { Magnetite accelerates the decomposition. }\end{array}$ & Qian et al . (1993). \\
\hline Decomposition & Amino acids, at high temperatures $\left(240^{\circ} \mathrm{C}\right)$. & Ala, Gly + Leu. & Quartz-fayalite-magnetite mixture & Amino acids are destroyed by heating at $240^{\circ} \mathrm{C}$. & Bada et al. (1995). \\
\hline Decomposition & $\begin{array}{l}\text { Amino acids at different temperatures, } \\
\text { controlling the oxidation state of the } \\
\text { environment. }\end{array}$ & $\begin{array}{l}\text { Ala, } \beta-\text { Ala, } \alpha \text {-ABA, Asp, Glu, } \\
\text { Gly, Leu, Ser, Val. }\end{array}$ & & $\begin{array}{l}\text { The decomposition rate is lower in high hydrogen fugacity } \\
\text { environments. }\end{array}$ & Kohara et al . (1997). \\
\hline Decomposition & $\begin{array}{l}\text { Stability of amino acids. At } 200^{\circ} \mathrm{C} \text { and } 50 \\
\text { bar in Teflon-coated autoclaves. }\end{array}$ & Ala, Asp, Leu, Ser. & $\begin{array}{l}\text { Pyrite-pyrrhotite-magnetite (PPM) to } \\
\text { constrain the oxygen fugacity. K-feldspar- } \\
\text { muscovite-quartz (KMQ) to control the } \\
\text { hydrogen ion activity. }\end{array}$ & $\begin{array}{l}\text { Gly, and Ala were formed, from Ser. } \\
\text { Decomposition rates of Leu, Ala and Asp lower in } \\
\text { experiments containing the PPM assemblage. }\end{array}$ & Andersson and Holm (2000). \\
\hline $\begin{array}{l}\text { Dimerization and } \\
\text { decomposition }\end{array}$ & $\begin{array}{l}\text { Influence of } \mathrm{P}(22.2 \text { and } 40.0 \mathrm{MPa}) \text { and } \mathrm{T} \\
\left(250,300,350,374,400^{\circ} \mathrm{C}\right) \text { in the } \\
\text { processes. }\end{array}$ & Gly. & N.A. & $\begin{array}{l}\text { Formation of Di-Gly, Tri-Gly (traces), diketopiperazine } \\
\text { and a } 433 \text { Da product. P \& T influence both dimerization } \\
\text { and decomposition. } \\
\text { Maximum dimers formation at } 350^{\circ}-375^{\circ} \mathrm{C}, 22.2-40 \\
\text { Mpa. }\end{array}$ & Alargov et al. (2002). \\
\hline Decomposition & $\begin{array}{l}\text { High-temperature }\left(200^{\circ} \text { to } 340^{\circ} \mathrm{C}\right) \text { and high- } \\
\text { pressure }(20 \mathrm{MPa}) \text {, in a continuous-flow } \\
\text { tubular reactor. }\end{array}$ & Ala, Asp, Leu, Phe, Ser. & N.A. & $\begin{array}{l}\text { Degradation rates Asp }>\text { Ser }>\text { Phe }>\text { Leu }>\text { Ala. } \\
\text { Two main reaction paths: deamination (Asp) to produce } \\
\text { ammonia and organic acids, and decarboxylation to } \\
\text { produce carbonic acid and amine. } \\
\text { Production of glycine and alanine from serine. }\end{array}$ & Sato et al. (2004) \\
\hline Decomposition & $\begin{array}{l}\text { Hydrothermal reaction kinetics. A custom- } \\
\text { built spectrophotometric reaction cell was } \\
\text { used. In situ observations. }\end{array}$ & Asp. & $\begin{array}{l}\text { Reactor type } \\
\text { Non inert (Ti-6-4 / Au reactor). } \\
\text { Inert reactor (Au reactor). }\end{array}$ & $\begin{array}{l}\text { The reaction kinetics of Asp is complicated, and highly } \\
\text { dependent on experimental conditions (P, T, catalytic } \\
\text { surfaces). }\end{array}$ & Cox and Seward (2007a). \\
\hline Decomposition & $\begin{array}{l}\text { Hydrothemal reaction kinetic. } \\
\text { A custom spectrophotometric reaction cell } \\
\text { was constructed. In situ observations. }\end{array}$ & $\alpha$-Ala, $\beta$-Ala, Gly. & N.A. & $\begin{array}{l}\text { Under certain hydrothermal conditions, } \alpha \text {-Ala, Gly,and } \\
\beta \square \text { Ala undergo dimerization and cyclization reaction } \\
\text { pathways. }\end{array}$ & Cox and Seward (2007b). \\
\hline Decomposition & $\begin{array}{l}\text { Decomposition of the amino acids sub- and } \\
\text { supercritical water. } \\
\text { The effect of T }\left(250^{\circ} \text { to } 450^{\circ} \mathrm{C}\right) \text {, and } \\
\text { residence time }(2.5 \text { to } 35 \mathrm{~s}), \mathrm{P}(34 \text { and } 24 \\
\text { MPa), and reactant concentration (1.0 and } \\
2.0 \% \text {, w:v). }\end{array}$ & Ala, Gly. & N.A. & $\begin{array}{l}\text { Decarboxylation and amino acid deamination reactions } \\
\text { were proposed for both molecules. }\end{array}$ & Klingler et al. (2007). \\
\hline Decomposition & $\begin{array}{l}\text { The effect of iron oxide and sulfide minerals } \\
\text { on decomposition reactions of an amino } \\
\text { acid. }\end{array}$ & Nva. & $\begin{array}{l}\text { Mineral assemblage } \\
\text { hematite-magnetite-pyrite (HMP) and } \\
\text { pyrite-pyrrhotite-magnetite (PPM). }\end{array}$ & $\begin{array}{l}\text { Nva decomposes by } 1 \text { ) decarboxylation followed by } \\
\text { oxidative deamination, and by 2) deamination directly to } \\
\text { valeric acid. } \\
\text { Minerals accelerated decomposition rates. } \\
\text { Decomposition is faster in presence HMP than PPM. }\end{array}$ & McCollom (2013). \\
\hline Stability & $\begin{array}{l}\text { Hydrothermal stability of alanine } \\
\text { oligopeptides. }\end{array}$ & $(\mathrm{Ala})_{3},(\mathrm{Ala})_{4},(\mathrm{Ala})_{5}$ & & $\begin{array}{l}\text { Small excess of oligopeptides longer than the starting } \\
\left.\text { ones. Elongation of (Ala) })_{4} \text { and (Ala) }\right)_{5} \text { was possible in Ala } \\
\text { excess. Elongation is competitive with degradation. }\end{array}$ & Kawamura et al. (2005). \\
\hline Stability & $\begin{array}{l}\text { To test the thermal stability of amino acids in } \\
\text { seafloor hydrothermal systems. }\end{array}$ & $\begin{array}{l}\text { Ala, Asp, Gaba, Glu, Gly, Leu, } \\
\text { Met, Ser. }\end{array}$ & $\begin{array}{l}\text { Carbonaceous ooze: } \\
\text { Calcite, with minor amounts of quartz } \\
\text { and huntite and traces of illite, smectite } \\
\text { and chlorite. }\end{array}$ & $\begin{array}{l}\text { The upper limit temperature for the stable presence was } \\
150^{\circ} \text { and } 200^{\circ} \mathrm{C} \text {. } \\
\text { AAs cannot be synthesized or survive at } \mathrm{T}>250^{\circ} \mathrm{C} \text {, }\end{array}$ & Ito et al. (2006). \\
\hline Stability & $\begin{array}{l}\text { Reactions of amino acids under subcritical } \\
\text { water conditions }\left(220^{\circ} \text { to } 290^{\circ} \mathrm{C}\right) \text {. }\end{array}$ & $\begin{array}{l}\text { Ala, Arg, Asp, Cys, Glu, Gly, } \\
\text { His, Ile, Leu, Lys, Met, Phe, Pro, } \\
\text { Ser, Thr, Tyr, Val. }\end{array}$ & N.A. & $\begin{array}{l}\text { A decrease in the overall stability in amino acids mixtures. } \\
\text { Most of the amino acids decompose at acidic and near- } \\
\text { natural } \mathrm{pH} \text {, stable at basic } \mathrm{pH} \text {. }\end{array}$ & Abdelmoez et al. (2007). \\
\hline Stability & $\begin{array}{l}\text { Evaluation of the thermal stability of amino } \\
\text { acids under alkaline hydrothermal conditions } \\
\left.\text { (an aqueous solution of } \mathrm{NaCl}_{\text {and }} \mathrm{Na}_{2} \mathrm{CO}_{3}\right) \\
\text { at high temperatures }\left(100^{\circ} \text { to } 300^{\circ} \mathrm{C}\right) \text {. }\end{array}$ & $\begin{array}{l}\text { Ala, Arg, Asp, } \beta \text {-Ala, Gaba, Glu, } \\
\text { Gly, His, Ile, Leu, Lys, Met, Orn, } \\
\text { Phe, Pro, Ser, Thr, Tyr, Val. }\end{array}$ & Siliceous ooze & $\begin{array}{l}\text { Compared with decomposition at neutral conditions, the } \\
\text { decomposition rates are lower under alkaline conditions. }\end{array}$ & Yamaoka et al. (2007). \\
\hline Stability & $\begin{array}{l}\text { Effect of the mineralogical and chemical } \\
\text { properties of host sediments on the thermal } \\
\text { stability of amino acids. }\end{array}$ & $\begin{array}{l}\text { Ala, Arg, Asp, } \beta \text {-Ala, Gaba, Glu, } \\
\text { Gly, His, Ile, Leu, Lys, Met, Phe, } \\
\text { Pro, Ser, Thr, Tyr, Val. }\end{array}$ & $\begin{array}{l}\text { Siliceous ooze: silica minerals (mostly } \\
\text { quartz and minor opaline silica); } \\
\text { moderate amounts of calcite and minor } \\
\text { amounts of smectite and illite. } \\
\text { Montmorillonite } \\
\text { Saponite (synthesized). }\end{array}$ & $\begin{array}{l}\text { The optimal temperature for amino acids was below } 150 \\
{ }^{\circ} \mathrm{C} \text {. } \\
\text { Amino acids are more stable at higher temperatures when } \\
\text { associated with silicates. }\end{array}$ & Ito et al. (2009). \\
\hline Stability & $\begin{array}{l}\text { Effects of temperature }\left(25^{\circ}, 150^{\circ}, 200^{\circ} \text { and }\right. \\
\left.250^{\circ} \mathrm{C}\right), \mathrm{pH}(6 \text { and } 10) \text { and redox state }(13 \\
\left.\mathrm{mM} \text { aqueous } \mathrm{H}_{2}\right) \text { of hydrothermal fluids. }\end{array}$ & Glu & N.A. & $\begin{array}{l}\text { Glutamic acid at high-temperatures cyclizes and forms } \\
\text { pyroglutamate. }\end{array}$ & Lee et al. (2014). \\
\hline
\end{tabular}

Note: All amino acids are abbreviated according to the IUPAC indications.

Key: ABA = aminobutyric acid, Ala = alanine, Arg = arginine, Asp = asparagine, Cys = cysteine, Gaba = gamma-aminobutyric acid, Glu = glutamic acid, Gly = glycine, His = histidine, Hyp = hydroxyproline, Ile = isoleucine, Leu = leucine, Lys = lysine, Met = metionine, $\mathrm{Nva}=$ norvaline, Orn = ornithine, PCA = pyroglutamic acid, Phe = phenylalanine, Pro $=$ proline, Pyr $=$ pyruvate, Ser $=$ serine, Thr $=$ threonine, $\mathrm{Tyr}=$ tyrosine, $\mathrm{Val}=$ valine. 
Table 3. Experiments of oligomerization and synthesis of organic molecules in physicochemical conditions that simulate those of hydrothermal vents.



Note: All amino acids are abbreviated according to the IUPAC indications.

Key: $\mathrm{ABA}=$ aminobutyric acid, Ala = alanine, $\mathrm{AMP}=$ adenosine monophosphate, $\mathrm{Arg}=$ arginine, $\mathrm{Asp}=$ asparagine, $\mathrm{Cys}=\mathrm{cysteine}, \mathrm{Gaba}$ = gamma-aminobutyric acid, Glu = glutamic acid, Gly = glycine, His = histidine, Hyp = hydroxyproline, lle = isoleucine, Leu = leucine, Lys = lysine, Met = metionine, $\mathrm{Nva}=$ norvaline, Orn = ornithine, $\mathrm{PCA}=$ pyroglutamic acid, $\mathrm{Phe}=$ phenylalanine, Pro $=$ proline, $\mathrm{Pyr}=$ pyruvate, Ser $=$ serine, $\mathrm{Thr}=$ threonine, $\mathrm{Tyr}=$ tyrosine, Val $=$ valine. $\mathrm{PP} \mathrm{i}=$ Pyrophosphate. 
stability experiments (Table 2), and comprises the majority of available studies. In these experiments, the decomposition rate of biomolecules, mainly amino acids, is explored. The most surveyed one is the simplest amino acid: glycine. It is noticeable that the inclusion of mineral phases is considered fundamental in breakdown experiments. In this regard, the role of some iron-rich minerals has been explored (e.g., magnetite, fayalite, pyrite, etc.); however, other minerals (e.g, quartz, feldspars, muscovite, calcite) are also used. In this kind of experiments the formation of other amino acids is also pursued. An important finding is that there is an order in the decomposition rates of the selected molecules (Vallentyne, 1964; see Table 2), and that decomposition strongly depends on factors (such as $\mathrm{pH}$, pressure, ionic strength, etc.) other than temperature. Another kind of information that can be obtained by means of these studies is the determination of kinetic parameters (Povoledo and Vallentyne, 1964) in order to predict the behavior of organic reactions.

A step forward in prebiotic chemistry is the formation of more complex molecules: oligomers. The reason for this is that life is based in macromolecules. In consequence, the formation of oligomers in hydrothermal vents has also been explored (Table 3). Again, most experiments deal with glycine (e.g., Huber and Wächtershäuser, 1998; Imai et al., 1999), but the oligomerization of alanine has also been addressed (Ogata et al., 2000; Kawamura et al., 2005). Oligomerization in hydrothermal vents is confirmed in some experiments (i.e. Islam et al., 2003; Kawamura et al., 2005; see Table 3).

Models for the synthesis of organic compounds include those associated with a variety of mineral-catalyzed reactions such as water-rock reactions (e.g. serpentinization), Fischer-Tropsch reactions, and FeS-driven synthesis. Experiments listed on Table 3 show the synthesis of different types of amino acids, as well as lipids and hydrocarbons.

Experiments related to (1) the adsorption of organic molecules onto minerals, those related to explore the possible role of mineral channels in the concentration, and (2) the reactivity of some orga- nics in hydrothermal vents are still scarce (Table $4)$.

Serpentinization has been proposed as a generator of drastic chemical, redox, $\mathrm{pH}$, and thermal gradients (Russell et al., 2013). In this way, the weathering of mafic and ultramafic rocks constitutes a sink for $\mathrm{CO}_{2}$ (Berndt et al., 1996), because minerals present in basalts (olivine, plagioclase and augite) are highly reactive with $\mathrm{CO}_{2}$. It is likely that hydrothermal systems of the early Earth were largely hosted by olivine-rich ultramafic rocks (e.g., komatiites) (Russell et al., 2010). The formation of serpentine, brucite, and magnetite produces large amounts of hydrogen and methane (Kelley, 1996). The sustained production of hydrogen creates strongly reducing environments yielding a favorable environment for organic synthesis (Holm et al., 2015). This process could have contributed to the subsequent formation of organic compounds on early Earth.

\section{Concluding remarks}

The origin of life remains one of the most fundamental issues in science, branching out into a wide array of disciplines. Processes that might have contributed to the inventory of organic compounds, not only on early Earth but also on early Mars, include mineral-catalyzed reactions; such reactions may have occurred on submarine hydrothermal systems.

One of the principal reasons for the great deal of attention paid to hydrothermal systems is that their physical and chemical conditions could have favored the synthesis of organic compounds out of inorganic precursors. In these systems minerals are quite abundant, and minerals may have aided in the transition from geochemistry to biochemistry. Such environments are likely to have met the requirements for the occurrence of chemical evolution and the subsequent origin of life. The synthesis/destruction of organic compounds lingers as a controversial topic and many efforts are devoted to testing the role of these systems in prebio- 
Table 4. Compilation of various types of experiments in physicochemical conditions that simulate those of hydrothermal vents.

\begin{tabular}{|c|c|c|c|c|c|}
\hline Type of Study & Description of the experiment & Organic molecule used & Mineral & Main findings & References \\
\hline Adsorption & $\begin{array}{l}\text { Adsorption-desorption experiments at } \\
80^{\circ} \mathrm{C} \text { for } 10 \text { days. }\end{array}$ & Lys & $\begin{array}{l}\text { Na-smectite (smectite }(>90 \%) \text {, a } \\
\text { small amount of cristobalite }(<10 \\
\%) \text { and traces of calcite and quartz. }\end{array}$ & $\begin{array}{l}\text { Thermal treatment originates stronger } \\
\text { smectite-lysine binding, by } \mathrm{H} \text { bonds between } \\
\mathrm{NH}_{3}^{+} \text {lysine groups and smectite basal } \mathrm{O} \\
\text { atoms. }\end{array}$ & Cuadros et al. (2009). \\
\hline Adsorption & $\begin{array}{l}\text { Batch adsorption experiments and } \\
\text { surface-complexation modeling to } \\
\text { study the interaction of L-aspartate onto } \\
\text { brucite at different ionic strength }\left(\mathrm{Ca}^{2+}\right. \\
\left.\text { or } \mathrm{Mg}^{2+}\right) \text {. }\end{array}$ & L-aspartate & Brucite. & 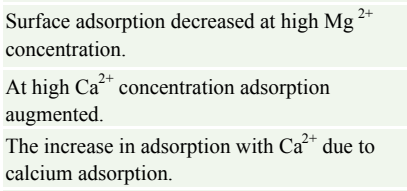 & Estrada et al. (2015). \\
\hline Reaction & $\begin{array}{l}\text { Decarboxylation of an amino acid } \\
\text { solution as a function of } \mathrm{pH}\end{array}$ & $\alpha$-Ala & N.A. & $\begin{array}{l}\text { Arrhenius parameters were determined. } \\
\text { The addition of } \mathrm{KCl} \text { resulted in a reduction of } \\
\text { the decarboxylation rate. }\end{array}$ & Li et al. (2002). \\
\hline Reactivity & $\begin{array}{l}\text { Pyruvate reactions in presence of } \\
\text { transition-metal sulfide minerals, at } \\
\text { moderate temperatures }\left(25^{\circ} \text { to } 110^{\circ} \mathrm{C}\right)\end{array}$ & Pyr & $\begin{array}{l}\text { Pyrrhotite, troilite, arsenopyrite, } \\
\text { pyrite, marcasite, sphalerite, } \\
\text { chalcopyrite }\end{array}$ & $\begin{array}{l}\text { Amino acids and fatty acids were formed. } \\
\text { Formation of lactate, propionate, and alanine, } \\
\text { among others. }\end{array}$ & $\begin{array}{l}\text { Novikov and Copley } \\
\text { (2013). }\end{array}$ \\
\hline Concentration & $\begin{array}{l}\text { To test if channels within the mineral } \\
\text { could act as act as natural } \\
\text { Clusius-Dickel thermal diffusion } \\
\text { column and increase local amphiphile } \\
\text { concentrations. }\end{array}$ & Oleic acid & Borosilicate microcapillaries. & $\begin{array}{l}\text { Microcapillaries act as a thermal diffusion } \\
\text { column and concentrated the molecule. } \\
\text { Vesicle formation. }\end{array}$ & Budin et al . (2009) \\
\hline Mineral precipitation & $\begin{array}{l}\text { Raman spectroscopy to study ancient } \\
\text { hydrothermal iron sulfide formation } \\
\text { (growth temperatures from } 40^{\circ} \text { to } 80 \\
{ }^{\circ} \mathrm{C} \text { ). }\end{array}$ & $\begin{array}{l}\text { Aqueous alkaline solutions } \\
\text { containing bisulfide and } \\
\text { silicate injected into iron (II) } \\
\text { solutions. }\end{array}$ & N.A. & $\begin{array}{l}\text { Formation of mackinawite and greigite iron } \\
\text { sulfide phases. } \\
\text { Mackinawite was probably the dominant } \\
\text { catalyst in ancient pre-biotic chemistry. }\end{array}$ & White et al. (2015). \\
\hline
\end{tabular}

Note: All amino acids are abbreviated according to the IUPAC indications.

Key: ABA = aminobutyric acid, Ala = alanine, AMP = adenosine monophosphate, Arg = arginine, Asp = asparagine, Cys = cysteine, Gaba = gamma-aminobutyric acid, Glu = glutamic acid, Gly = glycine, His = histidine, Hyp = hydroxyproline, lle = isoleucine, Leu = leucine, Lys = lysine, Met = metionine, $\mathrm{Nva}=$ norvaline, Orn = ornithine, $\mathrm{PCA}=$ pyroglutamic acid, $\mathrm{Phe}=$ phenylalanine, Pro $=$ proline, $\mathrm{Pyr}=$ pyruvate, Ser $=$ serine, $\mathrm{Thr}=$ threonine, $\mathrm{Tyr}=$ tyrosine, $\mathrm{Val}=$ valine.

tic chemistry. A better understanding of reaction pathways that led to the synthesis of organic molecules in prebiotic hydrothermal vents requires additional laboratory experiments under physical and chemical conditions as close as possible to the actual ones

\section{Acknowledgments}

The support of PAPIIT IA201114 and CONACyT 168579/11 research grants is acknowledged. Authors also want to thank GD Homero Heredia for the design of Figure 2 in this paper.

\section{References}

Abdelmoez, W., Nakahasi, T., Yoshida, H., 2007, Amino acid transformation and decomposition in saturated subcritical water conditions: Industrial \& Engineering Chemistry Research, 46, 5286-5294.

Alargov, D., Deguchi, S., Tsujii, K., Horikoshi, K., 2002, Reaction Behaviors of Glycine under Super- and Subcritical Water Conditions: Origins of Life and Evolution of the Biosphere, 32, 1-12.

AlDahan, A.A., 1990, Alteration and mass transfer in cataclasites and mylonites in 6.6 $\mathrm{km}$ of granitic crust at the Siljan impact structure, central Sweden: Contributions to Mineralogy and Petrology, 105, 662-676.

Alvarez, L.W., Alvarez, W., Asaro, F., Michel, H.V., 1980, Extraterrestrial Cause for the Cretaceous-Tertiary Extinction: Science, 208, 1095-1108.

Ames, D., Jonasson, I., Gibson, H., Pope, K., 2006, Impact-Generated Hydrothermal System Constraints from the Large Paleoproterozoic Sudbury Crater, Canada, in Cockell, C., Gilmour, I., Koeberl, C. (eds.), Biological 
Processes Associated with Impact Events: Impact Studies, Springer Berlin Heidelberg, $55-100$.

Andersson, E., Holm, N.G., 2000, The stability of some selected amino acids under attempted redox constrained hydrothermal conditions: Origins of Life and Evolution of the Biosphere, 30, 9-23.

Arehart, G.B., Christenson, B.W., Wood, C.P., Foland, K.A., Browne, P.R.L., 2002, Timing of volcanic, plutonic and geothermal activity at Ngatamariki, New Zealand: Journal of Volcanology and Geothermal Research, 16, 201-214.

Aubrey, A., Cleaves, H., Bada, J.L., 2009, The role of submarine hydrothermal systems in the synthesis of amino acids: Origins of Life and Evolution of the Biospheres, 39, 91-108.

Bada, J.L., Miller, S.L., Zhao, M., 1995, The stability of amino acids at submarine hydrothermal vent temperatures: Origins of Life and Evolution of the Biosphere, 25, 111-118.

Bada, J.L., Lazcano, A., 2003, Prebiotic Soup-Revisiting the Miller Experiment: Science 300, 745-746.

Barge, L.M., Doloboff, I.J., Russell, M.J., VanderVelde, D., White, L.M., Stucky, G.D., Baum, M.M., Zeytounian, J., Kidd, R., Kanik, I., 2014, Pyrophosphate synthesis in iron mineral films and membranes simulating prebiotic submarine hydrothermal precipitates: Geochimica et Cosmochimica Acta, 128, 1-12.

Baross, J.A., Hoffman, S.E., 1985, Submarine hydrothermal vents and associated gradient environments as sites for the origin and evolution of life: Origins of Life and Evolution of the Biosphere, 15, 327-345.

Barrie, C.T., Hannington, M.D., 1999, Classification of volcanic-associated massive sulfide deposits based on host-rock deposition: Reviews in Economic Geology, $8,1-11$
Baumgartner, R., Fontboté, L., Spikings, R., Schaltegger, U., Schneider, J., Page, L., Gutjahr, M., 2009, Bracketing the age of magmatic-hydrothermal activity at the Cerro de Pasco epithermal polymetallic deposit, Central Peru: A U-Pb and ${ }^{40} \mathrm{Ar} /{ }^{39} \mathrm{Ar}$ study: Economic Geology, 104, 479-504.

Belford, S.M., Davidson, G.J., McPhie, J., Large, R.R., 2015, Architecture of the Neoarchaean Jaguar VHMS deposit, Western Australia: Implications for prospectivity and the presence of depositional breaks: Precambrian Research, 260, 136-160.

Berndt, M.E., Allen, D.E., Seyfried, W.E., 1996, Reduction of $\mathrm{CO}_{2}$ during serpentinization of olivine at $300{ }^{\circ} \mathrm{C}$ and 500 bar: Geology, 24, 351-354.

Bernhardt, G., Lüdemann, H.-D., Jaenicke, R., König, H., Stetter, K.O., 1984, Biomolecules are unstable under "black smoker" conditions: Naturwissenschaften, 71, 583586.

Bernstein, M.P., Sandford, S.A., Allamandola, L.J., 1999, Life's far-flung raw materials [interstellar organic molecules]: Scientific American, 281, 26-33.

Budin, I., Bruckner, R.J., Szostak, J.W., 2009, Formation of protocell-like vesicles in a thermal diffusion column: Journal of the American Chemical Society, 131, 96289629.

Burcar, B.T., Barge, L.M., Trail, D., Watson, E.B., Russell, M.J., McGown, L.B., 2015, RNA Oligomerization in Laboratory Analogues of Alkaline Hydrothermal Vent Systems: Astrobiology, 15, 509-522.

Camprubí, A., Albinson, T., 2006, Depósitos epitermales en México: actualización de su conocimiento y reclasificación empírica: Boletín de la Sociedad Geológica Mexicana, 58, 27-81.

Camprubí, A., Albinson, T., 2007, Epithermal deposits in México - an update of current knowledge, and an empirical reclassification, 
in Alaniz-Álvarez, S.A., Nieto-Samaniego, A.F. (eds.), Geology of México: Celebrating the Centenary of the Geological Society of Mexico: The Geological Society of America Special Paper, 422, 377-415.

Camprubí, A., González-Partida, E., Torró, L., Alfonso, P., Miranda-Gasca, M.A., Martini, M., Canet, C., González-Sánchez, F., 2017, Mesozoic volcanogenic massive sulfide (VMS) deposits in Mexico: Ore Geology Reviews, 81 (P3), 1066-1083.

Cathles, L.M., Erendi, A.H.J., Barrie, T., 1997, How long can a hydrothermal system be sustained by a single intrusive event?: Economic Geology, 92, 766-771.

Chiaradia, M., Schaltegger, U., Spikings, R., Wotzlaw, J.-F., Ovtcharova, M., 2013, How accurately can we date the duration of magmatic-hydrothermal events in porphyry systems? Economic Geology, 108, 565-584.

Chyba, C.F., Phillips, C.B., 2007, Europa, in Sullivan, W.T., Baross, J.A. (eds.), Planets and life: The Emerging Science of Astrobiology, Cambridge U.P., 388-424.

Coffin, M.F., Eldholm, O., 1994, Large igneous provinces: crustal structure, dimensions, and external consequences: Reviews of Geophysics, 32, 1-36.

Collins, G.S., Melosh, H.J., Osinski, G.R., 2012, The Impact-Cratering Process: Elements, 8, 25-30.

Corbett, G.J., Leach, T.M., 1998, Southwest Pacific rim gold-copper systems; structure, alteration and mineralization: Society of Economic Geologists, Special Publication Series, 6, $238 \mathrm{p}$.

Corliss, J.B., Baross, J.A., Hoffman, S.E., 1981, An hypothesis concerning the relationship between submarine hot springs and the origin of life on Earth: Oceanologica Acta, Supplement, 59-69.

Cox, J.S., Seward, T.M., 2007a, The hydrothermal reaction kinetics of aspartic acid: Geochimica et Cosmochimica Acta, 71, 797-820.
Cox, J.S., Seward, T.M., 2007b, The reaction kinetics of alanine and glycine under hydrothermal conditions: Geochimica et Cosmochimica Acta, 71, 2264-2284.

Cuadros, J., Aldega, L., Vetterlein, J., Drickamer, K., Dubbin, W., 2009, Reactions of lysine with montmorillonite at $80^{\circ} \mathrm{C}$ : Implications for optical activity, $\mathrm{H}^{+}$transfer and lysinemontmorillonite binding: Journal of Colloid and Interface Science, 333, 78-84.

Daubar, I., Kring, D., 2001, Impact-induced hydrothermal systems: Heat sources and lifetimes, in 32nd Annual Lunar and Planetary Science: Houston Texas, USA, Conference Abstracts, 1727.

Delaye, L., Lazcano, A., 2005, Prebiological evolution and the physics of the origin of life: Physics of Life Reviews, 2, 47-64.

Estrada, C.F., Sverjensky, D.A., Pelletier, M., Razafitianamaharavo, A., Hazen, R.M., 2015, Interaction between l-aspartate and the brucite $\left[\mathrm{Mg}(\mathrm{OH})_{2}\right]$-water interface: Geochimica et Cosmochimica Acta, 155, 172-186.

Franklin, J.M., 1996, Volcanic-associated massive sulphide base metals, in Eckstrand, O.R., Sinclair, W.D., Thorpe, R.I. (eds.), Geology of Canadian mineral deposit types: Ottawa, Ontario, Canada, Geological Survey of Canada, Geology of Canada, 8, 158-183.

Franklin,J.M., Gibson, H.L., Jonasson, I.R., Galley, A.G., 2005, Volcanogenic massive sulfide deposits, in Hedenquist, J.W., Thompson, J.F.H., Goldfarb, R.J. (eds.), Economic Geology One Hundredth Anniversary Volume 1905-2005: Littleton, Colorado, USA, Society of Economic Geologists, 523560.

Franklin, J.M., Lydon, J.W., Sangster, D.M., 1981, Volcanic-associated massive sulfide deposits, in Skinner, B.J., (ed.), Economic Geology Seventy-fifth Anniversary Volume: Economic Geology Publishing Company, p. 485-627. 
French, B., 1970, Stability Relations of Siderite $\left(\mathrm{FeCO}_{3}\right)$, Determined in Controlled $\mathrm{fO}_{2}$ Atmospheres: Greenbelt, Maryland, Goddard Space Flight Center Report $\mathrm{X}-644-70-102,66 \mathrm{p}$

French, B.M., 1968, Progressive contact metamorphism of the Biwabik ironformation, Mesabi Range, Minnesota: Minnesota, University of Minnesota Press, $103 \mathrm{p}$.

Goodfellow, W.D., 1992, Chemical evolution of the oceans as discerned from the temporal distribution of sedimentary exhalative (SEDEX) Zn-Pb-Ag deposits, in International Geological Congress, Kyoto, Japan, Programs and Abstracts, 185.

Goodfellow, W.D., Lydon, J.W., Turner, R.J.W., 1993, Geology and genesis of stratiform sediment-hosted (SEDEX) zinc-lead-silver sulphide deposits: Geological Association of Canada Special Paper, 40, 201-252.

Hannington, M.D., de Ronde, G.E.J., Petersen, S., 2005, Sea-floor tectonics and submarine hydrothermal systems, in Hedenquist, J.W., Thompson, J.F.H., Goldfarb, R.J. (eds.), Economic Geology One Hundredth Anniversary Volume 1905-2005: Littleton, Colorado, USA, Society of Economic Geologists, 111-142.

Hedenquist, J.W., Arribas, A. Jr., Urien-Gonzalez, E., 2000, Exploration for epithermal gold deposits: Reviews in Economic Geology, 13, 245-277.

Holm, N.G., Andersson, E., 2005, Hydrothermal simulation experiments as a tool for studies of the origin of life on Earth and other terrestrial planets: a review: Astrobiology, 5, 444-160.

Holm, N.G., Charlou, J.L., 2001, Initial indications of abiotic formation of hydrocarbons in the Rainbow ultramafic hydrothermal system, Mid-Atlantic Ridge: Earth and Planetary Science Letters, 191, 1-8.

Holm, N.G., Oze, C., Mousis, O., Waite, J., GuilbertLepoutre, A., 2015, Serpentinization and the formation of $\mathrm{H}_{2}$ and $\mathrm{CH}_{4}$ on celestial bodies (planets, moons, comets): Astrobiology, 15, 587-600.

Horneck, G., 2006, Bacterial spores survive simulated meteorite impact, in Cockell, C., Koeberl, C., Gilmour, I. (eds.), Biological Processes Associated with Impact Events: Germany, Springer, 76-89.

Huber, C., Wächtershäuser, G., 1998, Peptides by activation of amino acids with $\mathrm{CO}$ on $(\mathrm{Ni}$, $\mathrm{Fe}) \mathrm{S}$ surfaces: implications for the origin of life: Science, 281, 670-672.

Imai, E.-i., Honda, H., Hattori, K., Brack, A., Matsuno, K., 1999, Elongation of oligopeptides in a simulated submarine hydrothermal system: Science, 283, 831-833.

Islam, M.N., Kaneko, T., Kobayashi, K., 2003, Reaction of Amino Acids in a Supercritical Water-Flow Reactor Simulating Submarine Hydrothermal Systems: Bulletin of the Chemical Society of Japan, 76, 1171-1178.

Ito, M., Gupta, L.P., Masuda, H., Kawahata, H., 2006, Thermal stability of amino acids in seafloor sediment in aqueous solution at high temperature: Organic Geochemistry, 37, 177-188.

Ito, M., Yamaoka, K., Masuda, H., Kawahata, H., Gupta, L.P., 2009, Thermal stability of amino acids in biogenic sediments and aqueous solutions at seafloor hydrothermal temperatures: Geochemical Journal, 43, 331-341.

Jébrak, M., Marcoux, E., 2008, Géologie des ressources minérales: Québec, Ministère des ressources naturelles et de la faune du Québec, 667 p.

Ji, F., Zhou, H., Yang, Q., 2008, The abiotic formation of hydrocarbons from dissolved $\mathrm{CO}_{2}$ under hydrothermal conditions with cobalt-bearing magnetite: Origins of Life and Evolution of Biospheres, 38, 117-125.

Kawamura, K., Nishi, T., Sakiyama, T., 2005, Consecutive elongation of alanine oligopeptides at the second time range under hydrothermal conditions using a microflow 
reactor system: Journal of the American Chemical Society, 127, 522-523.

Kelley, D.S., 1996, Methane-rich fluids in the oceanic crust: Journal of Geophysical Research: Solid Earth (1978-2012), 101, 2943-2962.

Kelley, D.S., Karson, J.A., Blackman, D.K., FruhGreen, G.L., Butterfield, D.A., Lilley, M.D., Olson, E.J., Schrenk, M.O., Roe, K.K., Lebon, G.T., Rivizzigno, P., and the, A.T.S.P., 2001, An off-axis hydrothermal vent field near the Mid-Atlantic Ridge at 30[deg] N: Nature, 412, 145-149.

Kirsimäe, K., Osinski, G.R., 2012, ImpactInduced Hydrothermal Activity, in Osinski, G.R., Pierazzo, E. (eds.), Impact Cratering: Processes and Products: Oxford, UK, WileyBlackwell, 76-89.

Klingler, D., Berg, J., Vogel, H., 2007, Hydrothermal reactions of alanine and glycine in sub-and supercritical water: The Journal of Supercritical Fluids, 43, 112-119.

Kohara, M., Gamo, T., Yanagawa, H., Kobayashi, K., 1997, Stability of amino acids in simulated hydrothermal vent environments: Chemistry Letters, 10, 1053-1054.

Kring, D.A., 1995, The dimensions of the Chicxulub impact crater and impact melt sheet: Journal of Geophysical Research: Planets, 100, 16979-16986.

Kring, D.A., Durda, D.D., 2002, Trajectories and distribution of material ejected from the Chicxulub impact crater: Implications for postimpact wildfires: Journal of Geophysical Research: Planets, 107, 6-1-6-22.

Lathe, R., 2004, Fast tidal cycling and the origin of life: Icarus, 168, 18-22.

Lathe, R., 2005, Tidal chain reaction and the origin of replicating biopolymers: International Journal of Astrobiology, 4, 19-31.

Lazcano, A., 2010, Which Way to Life?: Origins of Life and Evolution of Biospheres, 40, 161-167.

Laznicka, P., 2006, Giant metallic deposits, future sources of industrial minerals: Heidelberg,
Germany, Springer, 732 p.

Leach, D.L., Sangster, D.F., Kelley, K.D., Large, R.R., Garven, G., Allen, G.R., Gutzmer, J., Walters, S., 2005, Sediment-hosted lead-zinc deposits: a global perspective, in Hedenquist, J.W., Thompson, J.F.H., Goldfarb, R.J. (eds.), Economic Geology One Hundredth Anniversary Volume 1905-2005: Littleton, Colorado, USA, Society of Economic Geologists, 561-607.

Lee, N., Foustoukos, D.I., Sverjensky, D.A., Cody, G.D., Hazen, R.M., 2014, The effects of temperature, $\mathrm{pH}$ and redox state on the stability of glutamic acid in hydrothermal fluids: Geochimica et Cosmochimica Acta, 135, 66-86.

Lemke, K.H., Rosenbauer, R.J., Bird, D.K., 2009, Peptide synthesis in early Earth hydrothermal systems: Astrobiology, 9, 141-146.

Levin, H., 2009, The Earth through Time: New Jersey, John Wiley and Sons. 624 p.

Li, J., Wang, X., Klein, M.T., Brill, T.B., 2002, Spectroscopy of hydrothermal reactions, 19: $\mathrm{pH}$ and salt dependence of decarboxylation of a-alanine at $280-330^{\circ} \mathrm{C}$ in an FT-IR spectroscopy flow reactor: International Journal of Chemical Kinetics, 34, 271-277.

Luisi, P.L., 2014, Prebiotic metabolic networks?: Molecular Systems Biology, 10, 729.

Lydon, J.W., 1988, Volcanogenic massive sulphide deposits, part 2: genetic models, in Roberts, R.G., Sheahan, P.A. (eds.), Ore deposit models: St. John's New Foundland Canada Geological Association of Canada, Geoscience Canada, Reprint Series, 3, 155181.

Lydon, J.W., 1996, Sedimentary exhalative sulphides (sedex), in Eckstrand, O.R., Sinclair, W.D., Thorpe, R.I. (eds.), Geology of Canadian mineral deposit types: Ottawa, Canada, Geological Survey of Canada, Geology of Canada, 8, 130-152.

Lyons, T.W., Gellatly, A.M., McGoldrick, P.J., Kah, L.C., 2006, Proterozoic sedimentary exhalative (SEDEX) deposits and links to 
evolving global ocean chemistry: Memoir of the Geological Society of America, 198, 169-184.

Marshall, W.L., 1994, Hydrothermal synthesis of amino acids: Geochimica et Cosmochimica Acta, 58, 2099-2106.

Martin, W., Russell, M.J., 2007, On the origin of biochemistry at an alkaline hydrothermal vent: Philosophical Transactions of the Royal Society B: Biological Sciences, 362, 1887-1926.

McCarville, P., Crossey, L.J., 1996, Post-impact hydrothermal alteration of the Manson impact structure: Geological Society of America Special Papers, 302, 347-376.

McCollom, T.M., 2013, The influence of minerals on decomposition of the n-alkyla-amino acid norvaline under hydrothermal conditions: Geochimica et Cosmochimica Acta, 104, 330-357.

McCollom, T.M.,Seewald,J.S., 2003, Experimental constraints on the hydrothermal reactivity of organic acids and acid anions: I. Formic acid and formate: Geochimica et Cosmochimica Acta, 67, 3625-3644.

Melosh, H.J., Schneider, N.M., Zahnle, K.J., Latham, D., 1990, Ignition of global wildfires at the Cretaceous/Tertiary boundary: Nature, 343, 251-254.

Melosh, H. J., 2011, Planetary surface processes: New York, Cambridge University Press, 534 p.

Misra, K.G., 1999, Understanding mineral deposits: Dordrecht, The Netherlands, Kluwer Academic Publishers, 845 p.

Morowitz, H.J., 2002, The emergence of everything: How the world became complex: New York, Oxford University Press, 224 p.

Mossman, D.J., Gauthier-Lafaye, F., Jackson, S.E., 2005, Black shales, organic matter, ore genesis and hydrocarbon generation in the Paleoproterozoic Franceville Series, Gabon: Precambrian Research, 137, 253-272.

Muller, A.J., Schulze-Makuch, D., 2006, Thermal Energy and the Origin of Life: Origins of
Life and Evolution of Biospheres, 36, 177189.

Newsom, H.E., 2012, Impact crater hydrothermal processes in terrestrial analog craters and their implications for phyllosilicates in impact craters on Mars, Third Conference on early Mars.

Nisbet, E.G., Sleep, N.H., 2001, The habitat and nature of early life: Nature, 409, 1083-1091. LPI Contributions, 1680, 7065.

Novikov, Y., Copley, S.D., 2013, Reactivity landscape of pyruvate under simulated hydrothermal vent conditions: Proceedings of the National Academy of Sciences, 110, 13283-13288.

Ogata, Y., Imai, E., Honda, H., Hatori, K., Matsuno, K., 2000, Hydrothermal circulation of seawater through hot vents and contribution of interface chemistry to prebiotic synthesis: Origins of Life and Evolution of the Biosphere, 30, 527-537.

Ohmoto, H., 1996, Formation of volcanogenic massive sulfide deposits: The Kuroko perspective. Ore Geology Reviews, 10, 135177.

Orgel, L.E., 1998, The origin of life- a review of facts and speculations: Trends in Biochemical Sciences, 23, 491-495.

Orgel, L.E., 2000, Self-organizing biochemical cycles: Proceedings of the National Academy of Sciences, 97, 12503-12507.

Osinski, G.R., Lee, P., Parnell, J., Spray, J.G., Baron, M., 2005, A case study of impactinduced hydrothermal activity: The Haughton impact structure, Devon Island, Canadian High Arctic: Meteoritics \& Planetary Science, 40, 1859-1877.

Parnell, J., Lindgren, P., Osinski, G., Cockell, C., Lee, P., 2006, Simple devices for concentration of microbial life: Experiments in Haughton impact structure, in $37^{\text {th }}$ Annual Lunar and Planetary Science Conference (Vol. 37), 1050

Pašava, J., 1993, Anoxic sediments-an important environment for PGE: an overview: Ore 
Geology Reviews, 8, 425-445.

Pirajno, F., 2009, Hydrothermal Processes and Mineral Systems: East Perth, Australia, Springer. $1250 \mathrm{p}$.

Pope, K.O., Kieffer, S.W., Ames, D.E., 2006, Impact melt sheet formation on Mars and its implication for hydrothermal systems and exobiology: Icarus, 183, 1-9.

Povoledo, D., Vallentyne, J.R., 1964, Thermal reaction kinetics of the glutamic acidpyroglutamic acid system in water: Geochimica et Cosmochimica Acta, 28, 731-734.

Proskurowski, G., Lilley, M.D., Seewald, J.S., Früh-Green, G.L., Olson, E.J., Lupton, J.E., Sylva, S.P., Kelley, D.S., 2008, Abiogenic Hydrocarbon Production at Lost City Hydrothermal Field: Science, 319, 604-607.

Qian, Y., Engel, M.H., Macko, S.A., Carpenter, S., Deming, J.W., 1993, Kinetics of peptide hydrolysis and amino acid decomposition at high temperature: Geochimica et Cosmochimica Acta, 57, 3281-3293.

Rathbun, J.A., Squyres, S.W., 2002, Hydrothermal Systems Associated with Martian Impact Craters: Icarus, 157, 362-372.

Redmond, P.B., Einaudi, M.T., 2010, The Bingham Canyon porphyry Cu-Mo-Au deposit. I. Sequence of intrusions, vein formation, and sulfide deposition: Economic Geology, 105, 43-65.

Ross, P.-S., McNicoll, V.J., Debreil, J.-A., Carr, P., 2014, Precise U-Pb geochronology of the Matagami mining camp, Abitibi greenstone belt, Quebec: Stratigraphic constraints and implications for volcanogenic massive sulfide exploration: Economic Geology, 109, 89101.

Russell, M.J., Hall, A.J., 1997, The emergence of life from iron monosulphide bubbles at a submarine hydrothermal redox and $\mathrm{pH}$ front: Journal of the Geological Society, 154, 377-402.

Russell, M.J., Hall, A.J., Martin, W., 2010, Serpentinization as a source of energy at the origin of life: Geobiology, 8, 355-371.

Russell, M.J., Nitschke, W., Branscomb, E., 2013, The inevitable journey to being: Philosophical Transactions of the Royal Society of London B: Biological Sciences, 368, 20120254.

Sato, N., Quitain, A.T., Kang, K., Daimon, H., Fujie, K., 2004, Reaction kinetics of amino acid decomposition in high-temperature and high-pressure water: Industrial \& Engineering Chemistry Research, 43, 32173222.

Schopf, J.W., 2006, Fossil evidence of Archaean life: Philosophical Transactions of the Royal Society B: Biological Sciences, 361, 869-885.

Sillitoe, R.H., 2015, Epithermal paleosurfaces: Mineralium Deposita, 50,. 767-793.

Sillitoe, R.H., Hedenquist, J.W., 2003, Linkages between volcanotectonic settings, ore-fluid compositions, and epithermal precious metal deposits: Society of Economic Geologists, Special Publication, 10, 314-343.

Simmons, S.F., White, N.C., John, D.A., 2005, Geological characteristics of epithermal precious and base metal deposits, in Hedenquist, J.W., Thompson, J.F.H., Goldfarb, R.J. (eds.), Economic Geology One Hundredth Anniversary Volume 19052005: Littleton, Colorado, USA, Society of Economic Geologists, 485-522.

Smirnov, A., Hausner, D., Laffers, R., Strongin, D.R., Schoonen, M.A., 2008, Abiotic ammonium formation in the presence of Ni-Fe metals and alloys and its implications for the Hadean nitrogen cycle: Geochemical Transactions, 9, 5.

Stoffregen, R.E., 1987, Genesis of acid-sulfate alteration and $\mathrm{Au}-\mathrm{Cu}-\mathrm{Ag}$ mineralization at Summitville, Colorado: Economic Geology, 82, 1575-1591.

Vallentyne, J., 1964, Biogeochemistry of organic matter-II thermal reaction kinetics and transformation products of amino compounds: Geochimica et Cosmochimica Acta, 28, 157-188. 
Wächtershäuser, G., 1988a, Before enzymes and templates: theory of surface metabolism: Microbiological Reviews 52, 452-484.

Wächtershäuser, G., 1988b, Pyrite Formation, the First Energy Source for Life: a Hypothesis: Systematic and Applied Microbiology, 10, 207-210.

White, L.M., Bhartia, R., Stucky, G.D., Kanik, I., Russell, M.J., 2015, Mackinawite and greigite in ancient alkaline hydrothermal chimneys: Identifying potential key catalysts for emergent life: Earth and Planetary Science Letters, 430, 105-114.
White, N.C., Hedenquist, J.W., 1990, Epithermal environments and styles of mineralization: variations and their causes, and guidelines for exploration: Journal of Geochemical Exploration, 36, 445-474.

Yamaoka, K., Kawahata, H., Gupta, L.P., Ito, M., Masuda, H., 2007, Thermal stability of amino acids in siliceous ooze under alkaline hydrothermal conditions: Organic Geochemistry, 38, 1897-1909. 